\title{
The Poetics of Heritage: an inquiry into disaster.
}


THE POETICS OF HERITAGE: AN INQUIRY INTO DISASTER.

\section{ABSTRACT}

This paper argues that heritage is what contemporary culture makes of history and that this may distort our ability to face future realities. Funded by the UK Heritage Lottery Fund, the VIEWPOINT ecological arts project at the confluence of two rivers in Cockermouth, Northwest England, questioned the deployment of art and heritage as a means of community recovery from the 2009 and 2015 flood disasters. As the climate crisis accelerates and the psychosocial emergency increases, this project reassigned a Wordsworth poem and repurposed twelve large rocks to celebrate the potential for communities to live with their rivers in the future and defy their tendency towards nostalgia and memorialization. However, the situation was exacerbated when the United Nations Educational, Scientific and Cultural Organisation World Heritage awarded cultural heritage status on The Lake District National Park, affixing the environmental management of the area to Beatrix Potter's romanticized notion of sheep farming; thereby ensuring perpetual landscape deforestation and future flooding.

\section{Keywords}

Ecological Arts, Heritage, Dialogue, Climate-Futures, Floods, Rivers, Poetry. 


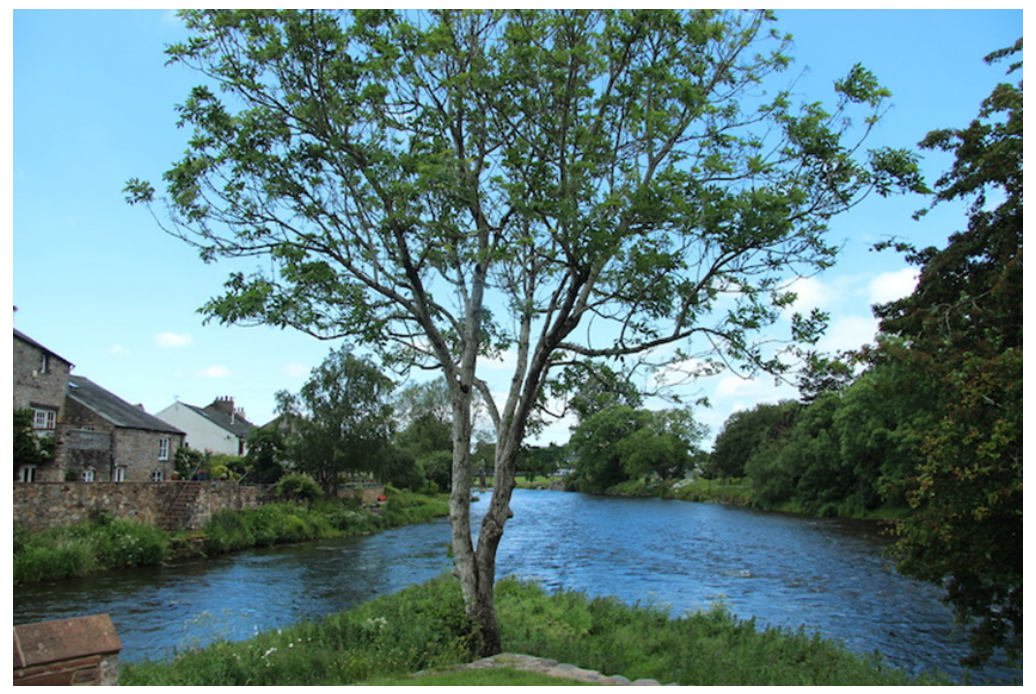

Figure 1. VIEWPOINT: confluence of the Rivers Cocker and Derwent. Photo: David Haley.

If a flashback, ten years since they said she died from the floods stress rains down on us

with false hopes and dreams the disaster industry once more cashing in scared of not being we still search for the answers the question's unknown nostalgic concerns ode to a dying ash tree futile and absurd we are forever our memory forever forever finite confluence of dreams a nature-culture catchment futures' heritage 
On the edge of The Lake District National Park, the market town of Cockermouth was the birthplace of the Romantic poet, William Wordsworth (1770-1850) (National Trust, 2020). 'His fine Georgian house is now a key tourist attraction. Heritage tourism forms one of the town's four inter-related, yet conflicting, socio-economic cultures; the others being farming, its geographic proximity to The Lakes and its commuting proximity to Sellafield Nuclear Power Station. For the townsfolk, the 'climate emergency (Denyer, 2019)' renders the nexus of these industries as dwelling in a paradox of psychosocial stress, ecological and economic collapse. This convergence is manifested in the town's name, as it evolved at the confluence of the River Cocker with the River Derwent. From here, the 2009 and 2015 flood events devastated the town. The VIEWPOINT ecological arts project (2017-19) attempted to address and resolve the disparate town communities' ability to adapt to potential future flooding.

\section{MAIN ARGUMENT}

\subsection{HISTORIC CONTEXT}

Under Roman occupation (71-410 AD) the landscape between the Lake District and the Irish Sea consisted of a complex forested delta system of waterways that drained from the Cumbrian mountains into the Irish Sea. These rivulets formed small, fertile islands awash with mineral deposits that flowed through these wetlands. This particular intersection of natural phenomena and the confluence of two main rivers were inhabited, celebrated and protected by a nearby settlement, temple and fort (Discovering Derventio, 2019).

The Medieval period (410-1485 AD) saw Viking, Saxon and Norman invasions and settlements in a large contested border region between Scotland and England. During this period the landscape slowly became simplified, with canalized rivers, increased arable farming and animal husbandry. Forests and wild animals, therefore decreased. In 1221, Cockermouth gained its Market Charter, further establishing it as a hub for agricultural trade and culture.

Through the 18th and 19th Centuries, the Industrial Revolution went hand-in-hand with the Agricultural Revolution and the start of climate change. This was predicted by the scientist, John Tindall (1820-1893) and art critic, John Ruskin (1818-1900) (Tyndall, 1872, Wheeler, 1995). From Cockermouth, William Wordsworth (1770-1850) attracted the Romantic Poets to celebrate the declining values of rural life, against the burgeoning mining, manufacturing and railway industries, as rural populations migrated to the rapidly expanding towns. The fast-flowing rivers, that had been famous for salmon and eels, provided power and water for manufacturing processes, and became highly polluted. Nearby, in the early 20th Century, conservationist and writer of children's books, Beatrix Potter (1866-1943), promoted the myth of a utopian rural idyll that centered on hill-top sheep farming. These were the seeds of the designated Lake District National Park (1951) and an ecologically unsustainable, economically unviable form of agricultural husbandry that denuded much of the landscape of trees, or as George Monbiot, the writer on political and environmental activism recently wrote: 'Our national parks are wiped clean, our natural heritage erased for the sake of an ersatz farm fantasy' (National Trust, Beatrix Potter; Monbiot, 2017).

By the mid 20th Century, twenty minutes by car from Sellafield nuclear power station, Cockermouth became an ideal hub for suburban floodplain residential development. While 
heritage tourism provided economic benefits, the floods of 2009 and 2015 devastated the town's economy and community welfare.

\subsection{THE VIEWPOINT PROJECT}

Learning from the floods, it seemed that the people of Cockermouth found great camaraderie from their plight and worked hard to support each other in the immediate aftermath (Pidd, 2015). However, they were ill prepared to foresee and cope with what may, now, be seen as the inevitable reoccurrence of intense rainfall. While much is being done by local residents, civic authorities and government agencies to physically reduce vulnerability to flooding impacts and promote Disaster Risk Reduction (Cumbria County Council, 2016), climate change psychology is beginning to understand the long-term traumatic effects of such events on individuals, effected communities and society as a whole (Hayes et al, 2018). This shift in psychosocial awareness opened up the possibility for an arts project to intervene.

The transformative challenges presented by Cockermouth's vulnerability run deep and wide, calling for an integrated interdisciplinary approach. While the concept of heritage provided a lens to see the shape of things, over time, an understanding of ecology provided 'the pattern that connects (Bateson, 2000, p. 512)' those things, over time. The practice of art, however, provided the process to transform those things into culture, over time. This process potentially turned 'the face of disaster to the face of opportunity (Harrison \& Harrison, 2008)'.

The VIEWPOINT project brought a wealth of community arts engagement and much climate related research, to listen to, engage with and empower the people of Cockermouth to creatively determine their 'capable futures (Haley, 2008)'. The main aim was to understand the form of Cockermouth's riparian history, and consider how this may promote community resilience. Through conversations, workshops and events the project developed a local lexicon, created new metaphors and shared myths for a futures-focused, eco-heritage narrative. As a dynamic 'dialogue (Bohm, et al, 1991)', these streams of consciousness later emerged as a poetic fable, carved in stone at the site of the confluence.

\section{METHOD: A CREATIVE PROGRAMME OF ARTS-LED RESEARCH}

A successful application to the Heritage Lottery Fund (HLF) was co-written by the Secretary of the locally-based, Riversmeet Community Cooperative, Cathy Newbery, and myself. Ms. Newbury had many years of experience as a Public Art curator and was assigned the role of Project Manager; providing contacts to community groups, local government agencies, managing the budget and relationship with the HLF. In acknowledgement of my experience as an ecological artist, I was invited to provide the creative input to the funding bid and was then appointed as the project Creative Practitioner.

Much of the programme was sketched out from an ecological arts perspective; that is, an arts practice that creatively connects social, cultural and environmental factors as the content and method of working. A particular dimension of this practice is referred to as 'eco-pedagogy (Haley, 2017; Khan 2010)' and this is concerned with how we may critically learn to live with our 
futures (Slaughter, 2003).

A Project Steering Group was constituted to ensure proper governance, contribute local knowledge and represent local interests. The members of this group consisted of: a Cumbria County councillor, the landscape architect and Town Centres Manager from Allerdale Borough Council, a local property developer, a storyteller and member of the Cockermouth Civic Trust, the community arts programmer and two members of the Cockermouth Heritage Group based at the Kirkgate Arts Centre. Ms. Newbery and I presented the project developments to the Steering Group six times from June 2017 to March 2019 and the Steering Group approved them. Each Steering Group member, also, provided their own anecdotes and some contributed directly to the creative programme.

Some elements of the main creative programme and research activities are described here:

\subsection{NAMING THE PROJECT}

The physical, geographic focus of the project was a small promontory of public recreational land, formed by the meeting of the Rivers Derwent and Cocker, named the Confluence Area. At the very first meeting, in preparation for the HLF application, the Allerdale Borough Council landscape architect, presented a plan drawing of amenity improvements that a local property developer had funded to improve the site to attract tourists. It was proposed that a public artwork monument to the floods be erected there, as this place signified their cause to some townsfolk. I noticed that on the drawing, at the tip of the peninsular, the word 'VIEW' with an arrow, pointed downstream. I queried the assumption and instruction to tourists for a 'photo opportunity', by saying that this was only one point of view and that the project and place could be a means of soliciting and representing diverse viewpoints from the local communities. Ms. Newbury then informed us that local people referred this Confluence Area as 'The Point'. Thereafter, the project was named VIEWPOINT and eighteen months later, the site was renamed 'VIEWPOINT' on the town's signpost.

\subsection{POSTCARD PROVOCATION: LISTENING AND LEARNING}

As a way to initially engage with the people of Cockermouth, 'intervene (Meadows, 1999)' in the flood disaster discourse and create a 'dialogue (Bohm, 1991)', a postcard was designed and printed. It had a photograph of the VIEWPOINT Confluence Area on the front and posed the questions: 'What is your point of view? How may we learn from Cockermouth's confluence? Why is heritage important for our futures?'. The reverse side of the postcard invited people to: 'Please write or draw your questions, ideas, stories, dreams or aspirations for living with the Rivers Derwent and Cocker here.'

As a means of introduction, talking point, aid memoir and provocation, the postcards were first distributed at the Cockermouth \& District Agricultural Show, July 2017. This annual event is aimed at the local farming community and is popular with visitors from within a 20-kilometre radius, including many of the towns and villages within the Derwent/Cocker river catchments.

A gazebo stall was erected on the Show site, with a water themed play area to attract children 
and their parents to consider the connection between water, rivers, catchment, flooding and their futures. To initiate conversation, the postcards were handed to all who visited the stall. The responses were mixed, with feedback ranging from celebrating river biodiversity to demonising the river floods for drowning a flock of sheep. This intervention was the start of the dialogical strategy that flowed (Bohm et al, 1991) through the whole project, whereby people from all walks of life shared their world views (Freire, 2017), in the hope that they might learn for themselves about their paradoxical relationship with the rivers.

\subsection{STORYING THE 'COCKERFISH' AND THE LANTERN PARADE}

To commemorate the 2009 flood, each year, on the last Friday of November, the Kirkgate Arts Centre produced a Lantern Parade with 200/300 local children and youths. However, over the years, the event had been appropriated by local retailers to generate publicity for Christmas shopping and the parade had been rerouted to pass as many shops as possible. The VIEWPOINT project provided an opportunity to consider less commercial values and to focus the event back on the rivers and in 2017 it was themed as the River Lantern Parade.

The author's previous experience of working with rivers in Taiwan, China and Hong Kong, brought some knowledge of Feng Shui, the ancient Chinese system of complex ecology. Based on this knowledge, the Confluence Area could be interpreted as the head of a land dragon and the rivers as two water dragons meeting - a very powerful convergence of energies. However, for most people of Northwest England, such a concept was culturally incongruous, so during a conversation with the local Youth Theatre Group about their contribution to the 2017 Lantern Parade, the idea of a mythological fish emerged. It transpired that in 2008, an extinct Ice Age fish, the' vendace' (Merrill, 2014), was rediscovered in Bassenthwaite, a lake that is a source of the River Derwent. An imaginary leap considered that if a similar fish was discovered in the River Cocker, it could be called, the 'Cockerfish'.

The Youth Theatre director, Jeff Wallcook, was engaged to develop this idea for the Cockermouth Heritage Open Days event, Storying the VIEWPOINT and a striking futuristic SciFi image of the mythical fish was designed for the Lantern Parade publicity material. Through the Youth Theatre workshops, the Cockerfish fable was developed by the youths into a large-scale, shadow puppet play for the finale of the Lantern Parade. The Cockerfish epitomised the 'Rivers' theme and a large fish head lantern was designed to lead the parade, with a lantern fish tail at the rear the whole parade representing the shape of the Cockerfish. The narrative of this mythological creature served as a metaphor to explore the paradoxical nature of the rivers to both sustain life and simultaneously threaten it. Through the development of this myth an imperative emerged from the youths for people to manage and care for the rivers; an attitude that had not been publicly expressed by the townsfolk before.

In the film of the VIEWPOINT project (Parks et al, 2019), it was interesting to note that members of the Youth Theatre Group thought that the myth of the Cockerfish was borrowed from traditional English folklore. The Cockerfish, therefore, became a vehicle for the Youth Group to explore their own understanding of heritage, invented in the present, with concerns for their futures. And while the following year's Lantern Parade developed the Rivers theme to focus on the town's river-based industrial history, in 2019 the Cockerfish returned by popular demand. 


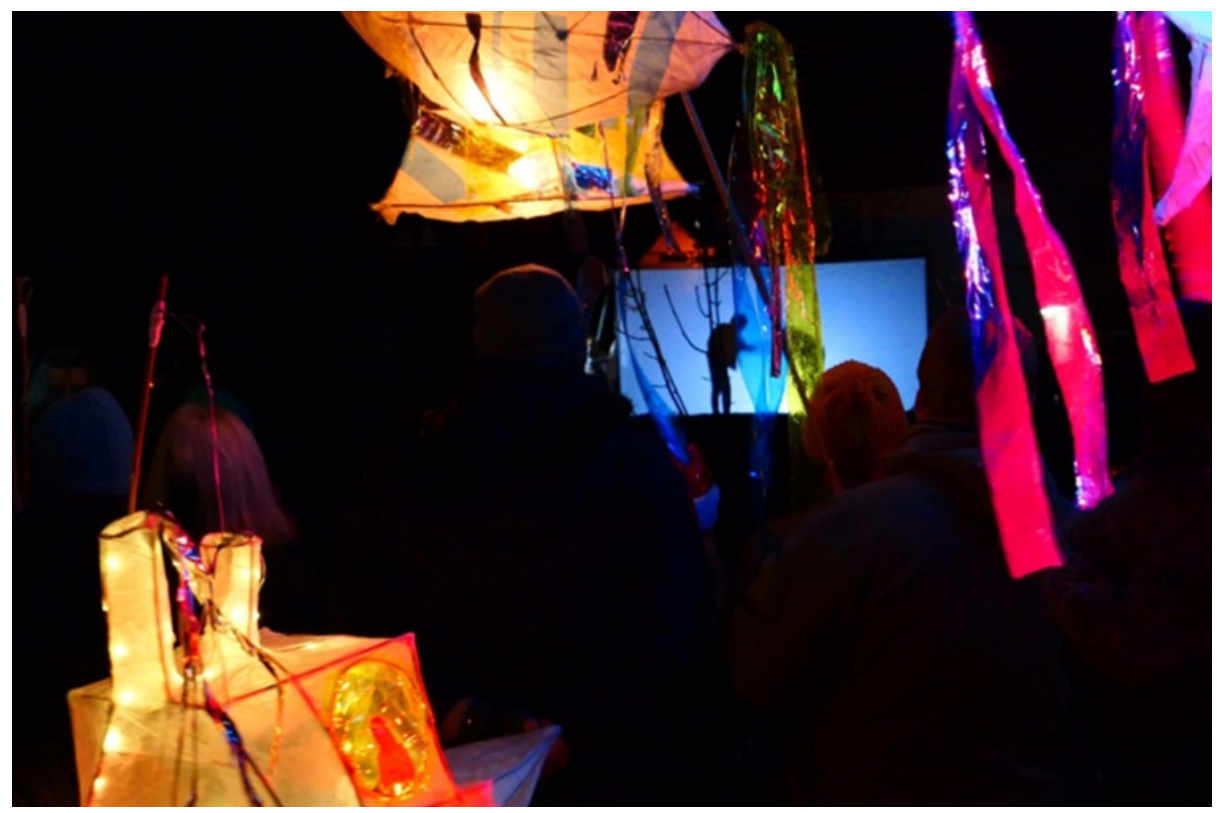

Figure 2. Rivers Lantern Parade 2017. Photo: David Haley.

The main physical deliverable for the Heritage Lottery Fund programme, at the Confluence Area, was envisioned as a permanent artwork installation on site by June 2018. However, the full programme included an extensive research process, prior to committing to any particular design. This included the Postcard Provocation, VIEWPOINT Storying, Schools Workshops, Lantern Making Workshops and the River Lantern Parade; each providing means for local listening, community cohesion and to determine the aspirations and prospects of the townsfolk. Likewise, a great deal of interdisciplinary and cross-sector research took place, including meetings with the Environment Agency to inquire of the potential for Natural Flood Defence systems, West Cumbria Rivers Trust to consider an educational liaison, the Chartered Institution for Water and Environmental Management Rivers and Coastal Group to be appraised of Cockermouth's geomorphological context, Cumbria Wildlife Trust to learn about local riverine biodiversity, Derventio archaeology to learn of the Roman presence, the Cockermouth Heritage and Geology groups, to learn about the town's industrial past and the importance of local mineral resources in terms of the vernacular architecture.

As time passed, members of the project Steering Group repeatedly asked, 'What is the artwork going to be?' Each time, the answer was given, 'The question is not, "what is the artwork", but "how does the art work?" This enigmatic reply created conceptual space to question preconceptions of heritage, the purpose and potential of public art. Indeed, the notion of a 'permanent artwork' in a transient world seemed incongruous and one that might perpetuate the myth of sustainability and the denial of change. Within the town, there were many plaques, 
noting the flood levels of recent disasters; a Heritage Wall, mural interpreting the town's history, that also featured the floods; and a kilometre stretch of the Derwent River bank designated as Memorial Garden.

The VIEWPOINT project, however, was not intended to further this culture of nostalgia, nor was it meant to contribute to the tourism industry per se. To this end, the project had deliberately not acknowledged the Romantic poet, William Wordsworth, who's childhood house is a major visitor attraction in the town. However, a visit to Florence Mine Arts Centre, at the nearby town of Egremont, serendipitously revealed a redundant public art sculpture by the renowned local artist, Conrad Atkinson. The sculpture, that pays homage to local haemotite miners, incorporated a quote from Wordsworth's poem, Resolution and Independence. In this autobiographical poem, Wordsworth repeatedly asks a lowly leech gatherer, 'How is it that you live and what is it you do? (Wordsworth, 1807)' As the project research had generated a series of poems, derived from conversations with the people of Cockermouth, finding this quote provided a key device to incorporate those poetic texts into the site artwork.

The poetic texts, themselves, were crafted into their form from the dialogue generated through the initial project research period. People's contributions were anonymized to present archetypical narratives, but some anecdotes had to be omitted as they were too personal for public display. Consideration was given to forming a flow or pattern that connected each poem and then become integral to the sculptural rock installation.

A draft of the poems was initially presented to the project Steering Group and some small amendments were adopted. The Haiku form of the poems was thought to be appropriate for the installation, as each poem was a brief text that conveyed one idea of the effects of flooding or the future of the rivers. Together they became a conversation between the two rivers as they met as a confluence. While the structure of a traditional Japanese Haiku poem was retained (three lines of three, seven and five syllables), in keeping with contemporary English adaptations, the style of content varied from the lyrical nature of Japanese convention (British Haiku Society). The poems are at the end of this article.

\subsection{SCULPTURAL INSTALLATION: REPURPOSING ROCKS}

This physical element of the VIEWPOINT programme, as intimated above, was perceived by the Steering Group and others as the main component. It certainly provided the tangible focus for many of the process-based aspects of the project and it remains on site as an enduring means of maintaining the dialogue about the rivers and their futures.

Twelve 2 ton, rocks formed two intertwined arcs that represent the pattern of waters meeting - the start of a vortex and the Taijitu, or YinYang symbol. Similar sized lumps of rock are used by the Environment Agency as coastal and river flood defenses. Originally, the types of rock to be used at the VIEWPOINT were to represent the geomorphology of the Derwent catchment and include, limestone, slate, bluestone, black/green basalt, haematite, yellow and red sandstone (the latter being a cultural introduction). This pot puree of rocks, that exist as cobbles on the river bed, were transported south from Scotland, by glaciers, in the last Ice Age. They were used extensively in the walls of local vernacular architecture. On reflection, this array of colours created by the rocks was considered to be aesthetically over complicated, so it was decided to 
have one arc of six slate rocks, representing nature, while the other arc of six red sandstone rocks, represented culture.

After some consideration, it was decided not to quarry the rocks for this sculptural installation, as this would run counter to the conservation principle of, 'keep it in the ground' (Howard \& Carrington, 2015). Cornhow Farm, by the River Cocker, in the Lorton Valley was identified as a source of six large pieces of red sandstone that had been salvaged from a dismantled, Victorian, railway bridge that had spanned the River Derwent. And in one of the farm's fields, by a tributary to the Cocker, six large pieces of slate were found. These had been removed from the shore of Buttermere, a source of the River Cocker. Each rock, therefore, had its own previous story, or embedded memory.

The town's resident haulage company, Lawson's, provided the logistics for transporting the rocks from Cornhow Farm to Jenning's Brewery Yard, next to the VIEWPOINT site. Here the rocks had the Haiku poems carved onto them by the eminent lettercarver, Pip Hall; the rocks becoming a form of heritage palimpsest. Over six weeks, visitors to the brewery were invited to extend their tour to see Pip and her local assistant, Ernie Thwaites plying their traditional skill to the rocks.

\subsection{GAINING PERMISSION}

The installation was specifically designed not to compromise any existing flood defences, nor worsen the effects of future floods, nor incur extra site maintenance, or environmental impact. Indeed, in consultation with Allerdale Borough Council's (ABC) landscape architect and the Environment Agency (EA) Rivers and Flood Defences Team, they identified the benefits of increased biodiversity, habitat niches, and promote social interaction by providing additional informal seating and new incidental play activities, with no detrimental impact on the rivers or flood events.

It was, however, necessary to gain Planning Permission from Allerdale Borough Council and this was granted in principle, but required a Licence or Exemption from the EA Licencing Department. Despite further meetings with the EA Rivers and Flood Defences Team, negotiations with the Licencing Department proved to be more difficult. Based on an erroneous citing of Archimedes' principle of water volume displacement, three Licence applications were refused and they insisted on a full hydrological consultant's analysis, that concurred with the project team assessment. A year later, the EA Licencing Department passed responsibility to proceed back to the VIEWPOINT project team.

While artworks in the public realm often meet with bureaucratic obstacles, the situation here was that the project inadvertently revealed systematic institutional issues, regarding flood risk management, that it had attempted to address. 


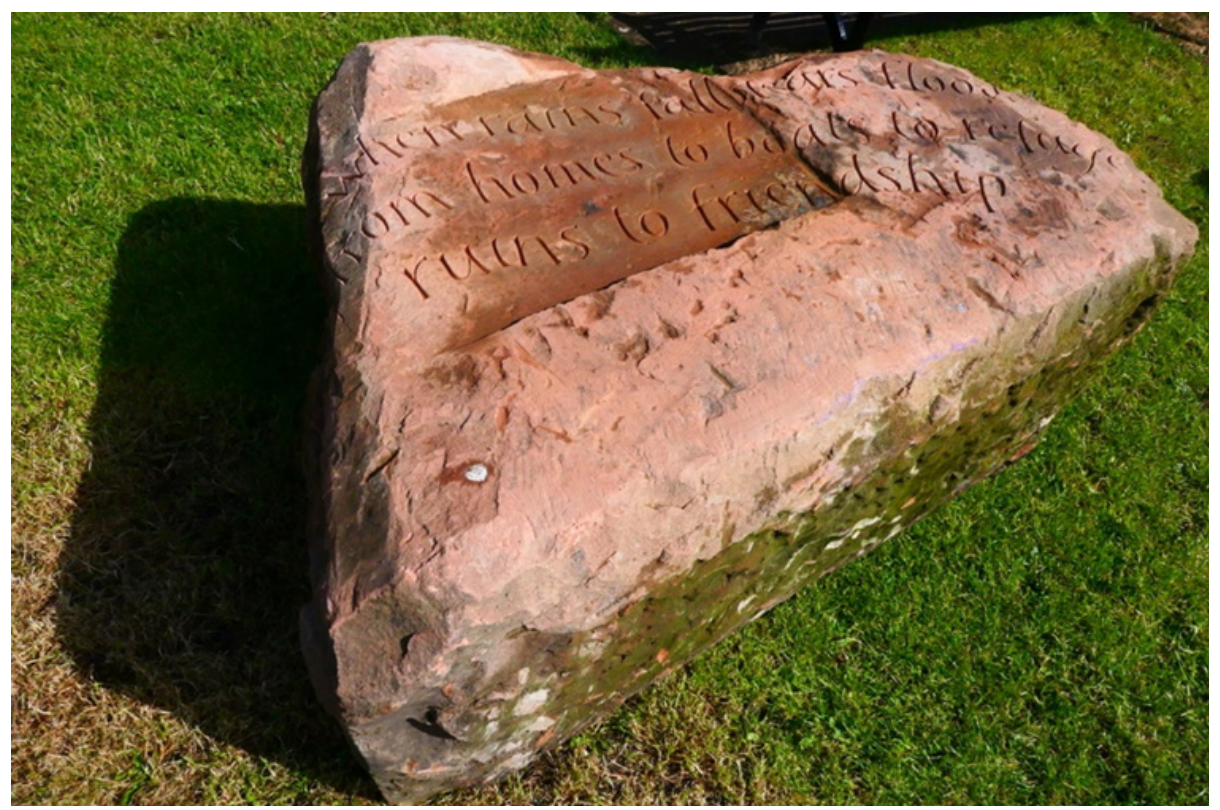

Figure 3. Haiku 8. Photo: David Haley.

\section{RESULTS AND EVALUATION}

The VIEWPOINT Evaluation Report to the Heritage Lottery Fund contained detailed descriptions, statistical data and budget spreadsheets, but some outcomes of the project emerged beyond the project's remit and funding. For instance, Riversmeet Community Cooperative, that initiated the project, have gained many new members through an on-going programme of Green Screenings at the Kirkgate Arts Centre. These began with a screening of the film Demain ([Tomorrow] Laurent eta al, 2015) at an interim presentation of the VIEWPOINT project. In addition to the planned research and creative outputs, several other initiatives emerged from the VIEWPOINT project process.

\subsection{PRESSING CONCERNS: THE GIFT OF WILDFLOWERS}

In July 2017, the Cockermouth Heritage Group's annual exhibition focused on the rivers and one of the exhibits inspired an additional VIEWPOINT development. A book of pressed wildflowers. The flowers had been collected and preserved in the book between 1885 and 1889 by the daughter of a local wealthy land owner who then givan the book as a gift to her gardener's daughter. The history of the treasured book provided the cultural narrative from which the local community could appreciate the past, understand the present and consider the future of natural flora, specific to Cockermouth.

A small community group wanted to make a similar book of contemporary wildflower pressings and poetry to celebrate the vernacular names of flowers. A trip was organized to meet Richard 
Scott, the Director of the National Wildflower Centre and he introduced them to the Botany Department at the Liverpool World Museum who generously provided scientific analysis and advice on conservation.

Pressing Concerns was designed to focus attention on the extinction of species, the need for biodiversity and the importance and beauty of wildflowers. The river catchment was, also understood to be a vital distributor of wildflower seeds. While floods have caused problems for rural and urban areas alike, the role of wildflowers in maintaining riverbank integrity was promoted as a contribution to natural flood defenses.

Historically, wildflower pressing may be seen as both a cultural and scientific activity, a socioecological practice or disciplinary symbiosis. Cockermouth townsfolk and the wider community $\mathrm{n}$ : ay use this activity to compare the past with the present and explore the future of biodiversity through the gift of wildflowers. When it is complete, their book will be exhibited at Kirkgate Arts Centre in Cockermouth, and the aim is to publish 500 copies of a smaller version of the book, to be gifted to those who participate in the project.

\subsection{RHYMING RIVERS}

Initiated after the Second World War, the modern concept of twin towns forms the basis of social and cultural agreements between towns of different nationalities, and in 2018 Cockermouth celebrated 35 years of twinning with Marvejois, France (Walker, 2018), which has introduced many educational exchanges. However, starting with the Cocker and the Derwent rivers, the VIEWPOINT project wanted to explore a different form of twinning, based on the idea that all the waters of the biosphere are connected. Contacts were made to artists in other parts of the world who are working with rivers, as a process of Rhyming Rivers. Just as one drop of water touches and joins another, so this tentative initiative has connected with river projects in Spain, Taiwan, the USA, Canada and Australia. As the pattern of rivers are naturally determined by heat, gravity and the connectivity of water, so this project will flow through 'conversational drift (Adcock, 1992:39)', as a kind of 'phenomenological, psychogeographic (Farina, 2014)', 'dérive (Debord, 1956)'.

\subsection{THE VIEWPOINT FILM}

The project budget did not stretch to the design and maintenance of a dedicated website and protracted attempts to produce a project film with the local high school failed. However, as a snapshot of the project's processes and activities, a film commissioned from Signal Films and Media, captures many views of the participants (Parks et al, 2019). Following the first public screening at the Kirkgate Arts Centre to the people of Cockermouth, on 18 September 2019, personal feedback indicates that the film has gained hundreds of hits on YouTube, taking the dialogue beyond Cockermouth to communities facing similar issues in many parts of the world. 


\section{DISCUSSION / CONCLUSION: WHAT HAS ART GOT TO DO WITH IT?}

\subsection{DELUGE: RESILIENCE IN VULNERABILITY}

In 2009 and again in 2015, the small market town of Cockermouth, in Northwest England, experienced disastrous flooding. The scale of each event was 1:1000 years. While nobody was directly killed as a result of the flooding, many homes, businesses and people's lives were devastated by the traumatic experiences.

Two years after the 2015 flood event, the Environment Agency (EA) published a booklet for the residents, entitled, 'What to do before, during and after a flood: Practical advice on what to do to protect yourself and your property (Environment Agency, 2017)'. From the responses of residents (Environment Agency, 2017; Heaslip, 2017) who suffered being flooded, it was painfully obvious that the anonymous author had never experienced such an event themselves and expressed little empathy. In other words, the national government authority had not prepared the townsfolk for such an event, were unable to respond at the time of the event and then demonstrated their lack of local knowledge and insensitivity to the situation in print.

People of the town repeatedly called for action during the aftermath, but the response has been largely limited to developing electronic, web-based, early warning communication systems (Cockermouth Emergency Response Group, 2016). However, the nature of both the 2009 and 2015 floods were such that they could not have been predicted and electrical power was lost each time, which would render such systems useless. The UK experiences similar events occur every year now (BBC, 2016; Flood List, 2017; The Guardian, 2017; Busby, 2018; Telegraph, 2018) and in November 2019, as this paper was being written, there were floods from the South West, across the Midlands to North East England, where the effects were severe (Gov.UK, 2019). June/July 2019 were both the hottest and wettest on record, with floods across the UK (Baker, 2019; BBC News 2019).

In response to public demand from the people of Cockermouth, the EA did build flood defence walls and installed large gates, that took three years to complete (Cockermouth Flood Action Group, 2016). A County Councilor campaigned to replace the pedestrian bridge that crosses the Derwent, as it was claimed that this caused the floods, when trees and debris were caught by the pier columns. However, from the geomorphological research (Barlow 2010a), the cause of the floods was excess water from unprecedented rainfall, flowing rapidly through the treeless landscapes (Barlow, 2010b). When viewed from the scale of the whole river catchment, this process of flooding is obvious, but personal experience of such events is more immediate. In fact, both deductions are correct, as such events occur as a combination of many factors that are inherited, incidental and often unknown (Global Commission on Adaptation, 2019).

The ability to comprehend complex, variability and adapt flexibly to indeterminate situations defines the difference between 'engineered resilience and ecological resilience (Gundersen and Holling, 2002)'. The former is concerned with sustaining a perceived steady state of existence, while the latter responds to the reality of shocks to a system that may even flip into another state of being. In a state of 'emergency' or 'crisis' such situations may be difficult to comprehend, let alone respond to. To recognise and own our vulnerability may, therefore, be seen as a positive advantage. To live in the knowledge that floods will return again, is the first step towards being 
prepared, being resourced, being trained, being vigilant and being able to then recover for the next event. Counter to the idea of Sustainable Development, this culture of 'capable futures (Haley, 2008)' may contribute to people's 'Disaster Risk-Reduction and Recovery (Davis and Alexander, 2016)' by developing an grounded, community-based, self-determined capacity. It may also increase their adaptive powers and may, in turn, enhance the Sendai Framework, international standard for disaster management (United Nations, 2015) as an embedded cultural attribute for the art of resilience.

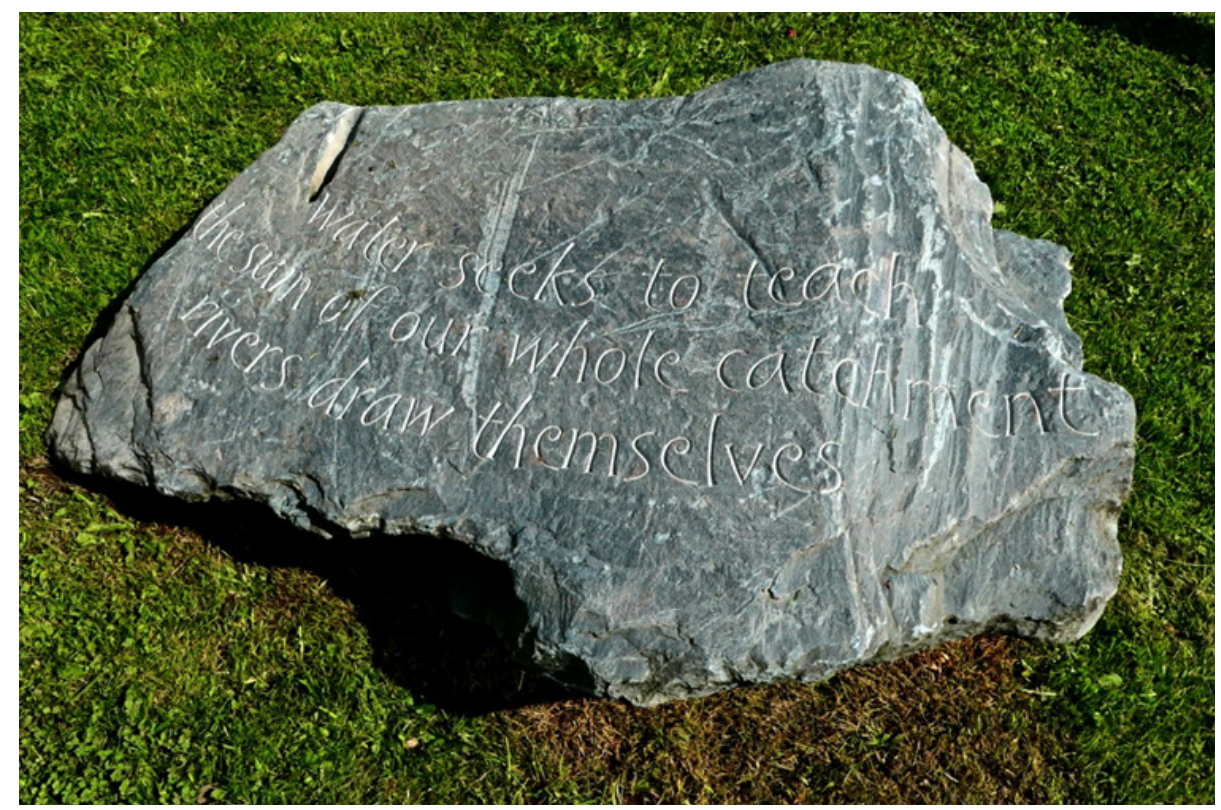

Figure 4. Haiku 2. Photo: David Haley.

\subsection{CULTURAL PARADOX}

During the application process, initial feedback from the HLF asked for 'clarity of the heritage outcomes', however, as local artist, Conrad Atkinson pointed out, 'heritage freezes history' (Atkinson, 2001). That is, much of the heritage UK society consumes through the tourism industry is focused on a particular construction of sanitised, post-industrial nostalgia, designed for tourism marketing. This brands places in an idealised and often a fixed period of history. Such heritageisation gained particular significance for Cockermouth in 2017 when UNESCO awarded the Lake District, World Heritage status for its culture (BBC, 2017). That culture is based on Beatrix Potter's promotion of 19th Century 'upland sheep farming (Rebanks, 2016)' that, in turn, has deforested much of the upstream landscape of the Lake District National Park from which the rivers of Cockermouth flow. The loss of trees contributes greatly to the fast run off of water that causes flash flooding and the rivers will now continue to flood in perpetuity (Monbiot, 2017). The paradox, therefore, exists between those who rely on subsidised sheep farming and heritage tourism for their livelihood and the future of persistent flood disasters. This state of 
affairs can generate angry conflicts of interest that the VIEWPOINT project processes identified and resolved, in that the realities of the situation were made clear. Considering these difficult questions is something that art may legitimately attempt to do, as it has no vested interest other than to intervene in the cultural narratives.

\subsection{FUTURES HERITAGE}

To sustain their place of dwelling, the people of Cockermouth may learn from the viewpoints they expressed. These were offered back to them in the form of the poetic texts that were carved onto the rocks, thereby permitting them to identify and then 'pose the problems (Freire, 2017)' they face. The twelve poems incorporated a reassigning of Wordsworth's poem, Resolution and Independence to Resolution and Interdependence, as a fabled conversation between the two rivers, to move attention from an individual, existential inquiry, to one that reflects upon community self-determination. The texts were carved onto locally sourced, repurposed rocks. The rocks, which are often used in public artworks to memorialize past events were, in this case, used to critically celebrate the possibility of diverse futures; thereby shifting heritage from a cultural freezing of history to the prospect of ecological resilience and futures heritage. Hopefully, their story will become an on-going affirmation of community spirit and conviviality, grounded in the realities of the transformative challenges we all face. Meanwhile, the rivers will continue to redraw the memory of their original paths with each future flood event - a dynamic, transient, living heritage. 
towards the sunset

to the sea and ocean's gyre

do-si-do-si-do

where we become one

a whirling revolution

one becomes many

gravity and heat

vision of many prospects

this climate of change

fluid perspectives

we flow in parallel time

past, present, future

water seeks to learn

the sum of our whole catchment

rivers draw themselves

"Cocker," says Derwent

"how is it that we live and what is it we do?"

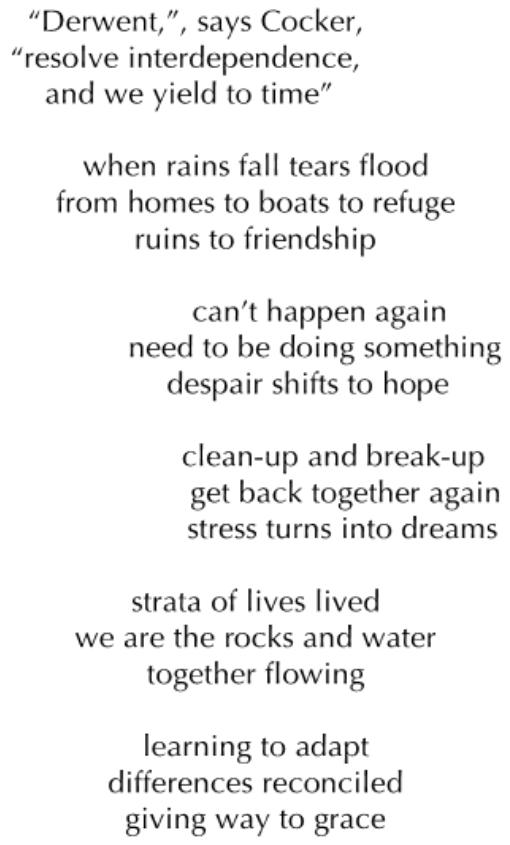

Figure 3. VIEWPOINT poetic texts, arranged as they are positioned on the installation of rocks. Photo: David Haley, 2019. 


\section{References}

Adcock, C. (1992). Conversational Drift: Helen Mayer Harrison and Newton Harrison. Art Journal Vol.51 (2), 35-45. doi: 10.1080/00043249.1992.10791564

Baker, L. (2019, July 15). UK Hydrological Status Update - July 2019. UK Centre for Ecology \& Hydrology. Retrieved from https:// www.ceh.ac.uk/news-and-media/blogs/uk-hydrological-statusupdate-july-2019

Barlow, J. (2010a) PSA3 Riverine SSSI Restoration Visions: November 2009 Flood Impacts Survey. Report B1284600/PF1. Jacobs.

Barlow, J. (2010b) PSA3 Riverine SSSI Restoration Visions: River Derwent Catchment - Technical Report. Report B12864000/D01. Jacobs.

Bateson, G. (2000). Steps to an ecology of mind. Chicago: University of Chicago Press.

BBC News (2016, June 7). Flash flooding causes chaos in parts of England. Retrieved from https://www.bbc.co.uk/news/ukengland-london-36471889

BBC News (2019, June 11). UK weather: Heavy rain causes road and rail disruption. Retrieved from https://www.bbc.co.uk/news/ uk-england-kent-48591882

BBC, (2017, July 9). Unesco awards Lake District World Heritage site status. Retrieved from https://www.bbc.co.uk/news/ukengland-cumbria-40547691

Bohm, D., Factor, D. and Garrett, P. (1991). Dialogue, A Proposal. Retrieved from http://www.david-bohm.net/dialogue/dialogue_ proposal.html

British Haiku Society (2011, February 13). Retrieved from http:// britishhaikusociety.org.uk/2011/02/english-haiku-a-compositeview/

Busby, M. (2018, October 13). Storm Callum: rivers burst banks in Wales as downpours intensify. The Guardian. Retrieved from https://www.theguardian.com/uk-news/2018/oct/13/storm-callum-expected-to-bring-more-heavy-rain-and-flooding-to-uk

Cockermouth Emergency Response Group (2016, October 9). Coc- 
kermouth Flood Action Group. Retrieved from http://www.cockermouthfloodactiongroup.org.uk/2016/10/

Cockermouth Flood Action Group (2016, October 1). Environment Agency Proposals. Retrieved from http://www.cockermouthfloodactiongroup.org.uk/2016/10/environment-agency-proposals/

Cumbria County Council (2016). Cockermouth S.19 Flood Investigation Report. Retrieved from https://www.cumbria.gov.uk/ elibrary/Content/Internet/544/3887/6729/6730/4306792559. pdf?timestamp $=4385116013$

Davis, I. \& Alexander, D. (2016). Recovery from Disaster. Abingdon, UK: Routledge.

Debord, G. (1956) Theory of the Dérive. Les Lèvres Nues\#9 (November 1956) reprinted in Internationale Situationniste \#2 (December 1958) Translated by Ken Knabb. Situationist International Online. Retrieved from https://www.cddc.vt.edu/sionline/si/ theory.html

Denyer, C. (2019, May 3). Climate change: What is a climate emergency? BBC News. Retrieved from https://www.bbc.co.uk/news/ newsbeat-47570654

Discovering Derventio (2019). Retrieved from http://www.discoverderventio.co.uk/

Environment Agency (2017). What to do before, during and after a flood: Practical advice on what to do to protect yourself and your property. Bristol, UK: Environment Agency. Retrieved from https://assets.publishing.service.gov.uk/government/uploads/ system/uploads/attachment_data/file/403213/LIT_5216.pdf

Farina, G. (2014). Some reflections on the phenomenological method. Dialogues in Philosophy, Mental and Neuro Sciences. 7(2), 50-62.

Flood List (2017, August 10). UK - Summer Storm Brings Flooding to Eastern and Southern England. Retrieved from http:// floodlist.com/europe/united-kingdom/flood-eastern-englandaugust-2017

Freire, P. (2017). Pedagogy of the Oppressed. London, UK: Penguin Modern Classics.

Global Commission on Adaptation (2019). Adapt Now: A Global Call for Leadership on Climate Resilience. Retrieved from 
https://cdn.gca.org/assets/2019-09/GlobalCommission_Report_ FINAL.pdf

Gov.UK Flood Information Service (2019). Retrieved from https:// flood-warning-information.service.gov.uk/warnings

Gunderson, L. H. \& Holling, C. S. (Eds) (2002). Panarchy: Understanding Transformations in Human and Natural Systems. Washington, D.C.: Island Press.

Haley, D. (2008). The Limits of Sustainability: The Art of Ecology. In S. Kagan and V. Kirchberg (eds.). Sustainability: a new frontier for the arts and cultures. Frankfurt, Germany: VAS-Verlag.

Haley, D. (2017) 'Undisciplinarity' and the Paradox of Education for Sustainable Development. In Leal Filho, W. (ed.) Handbook of Sustainable Science and Research. Series, Climate Change Management. Berlin: Springer Press.

Harrison, H. M. \& Harrison, N. (2008). Public Culture and Sustainable Practices: Peninsula Europe from an ecodiversity perspective, posing questions to Complexity Scientists. Structure and Dynamics, 2(3). Retrieved from http://repositories.cdlib.org/imbs/ socdyn/sdeas/vol2/iss3/art3

Hayes, K., Blashki, G., Wisema, J., Burke, S., \& Reifels, L. (2018). Climate change and mental health: risks, impacts and priority actions. International Journal of Mental Health Systems. 12(28) https://doi.org/10.1186/s13033-018-0210-6

Heaslip, M., \& Grimshaw, H. (2017). Environmental cost of flooding: A report by URBED (Urban Environment and Design) Ltd as part of the Big Lottery funded 'Rebuilding Together project in Cumbria. CAfS Cumbria Action for Sustainability. Retrieved from https://cafs.org.uk/wp-content/uploads/2019/01/Environmental-cost-of-flooding-report-CAfS.pdf

Howard, E., \& Carrington, D. (2015, March 16). Everything you wanted to ask about the Guardian's climate change campaign. The Guardian. Retrieved from https://www.theguardian.com/environment/2015/mar/16/everything-you-wanted-to-ask-aboutthe-guardians-climate-change-campaign

Khan, R. V. (2010). Critical Pedagogy, Ecoliteracy \& Planetary Crisis: The Ecopedagogy Movement. New York: Peter Lang Publishing Inc.

Laurent, M., Gion, C., \& Levy, B. (2015). The film Travel the world 
of solution. Demain le Film. Retrieved from https://www.demainlefilm.com/en/film

Meadows, D.H. (1999). Leverage Points: Places to intervene in the system. Sustainability Institut. Retrieved from http://donellameadows.org/archives/leverage-points-places-to-intervene-in-asystem/

Merrill, J. (2014, October 8). Extinct fish found in the Lake District after millions is spent on clean-up work. Independent. Retrieved from https://www.independent.co.uk/environment/extinctfish-found-in-the-lake-district-after-millions-spent-on-clean-upwork-9782933.html

Monbiot, G. (2017, July 11). The Lake District's world heritage site is a betrayal of the living world. The Guardian. Retrieved from https://www.theguardian.com/commentisfree/2017/jul/11/lakedistrict-world-heritage-site-sheep

National Trust, Beatrix Potter the farmer. Retrieved from https:// www.nationaltrust.org.uk/beatrix-potter-gallery-and-hawkshead/features/beatrix-potter-the-farmer

National Trust, Wordsworth House and Garden. Retrieved from https://www.nationaltrust.org.uk/wordsworth-house-and-garden

Parks, J., Pickford, A., \& Borgia, J. (2019). Viewpoint: a dialogue between rivers, people and their futures. Signal Films and Media. Retrieved from http://www.signalfilmandmedia.com/viewpoint/

Pidd, H. (2015, December 7). 'I can't go through this again': Cumbrians struggle with floods aftermath. The Guardian. Retrieved from https://www.theguardian.com/environment/2015/dec/07/ cumbria-floods-cockermouth-storm-desmond-town-comes-toterms-with-damage

Rebanks, J. (2016). A Shepheard's Life: A Tale of the Lake District. London: Penguin.

Slaughter, R. (2003). Futures Beyond Dystopia: Creating social foresight. London: Routledge.

Telegraph (2018, November 10). UK weather: Heavy rain and gales bring flooding to England and Wales. Retrieved from https:// www.telegraph.co.uk/news/2018/11/10/uk-weather-heavy-raingales-bring-flooding-england-wales/ 
The Guardian (2017, November 23). 70 rescued from floods as severe UK weather continues. Retrieved from https://www.theguardian.com/uk-news/2017/nov/23/dozens-rescued-from-floodsas-severe-uk-weather-continues (Accessed 13 November 2019)

Tyndall, J. (1872). Contributions to Molecular Physics in the domain of Radiant Heat. London: Longmans, Green and Co. Retrieved from https://archive.org/stream/contributionsto01tyndgoog\#page/ n441/mode/1up

United Nations (2015). Sendai Framework for Disaster Risk Reduction 2015-2030. UN World Conference on Disaster Risk Reduction. 14-18 March 2015. Sendai (Japan). Retrieved from https://www. wcdrr.org/preparatory/post2015/

Walker, T. (2018, October 17). Cockermouth celebrates 35 years of twinning with Marvejols. Times \& Star. Retrieved from https:// www.timesandstar.co.uk/news/17011348.cockermouth-celebrates-35-years-of-twinning-with-marvejols/

Wheeler, M. (1995). Ruskin and Environment: The Storm-Cloud of the Nineteenth Century. Manchester: Manchester University Press.

Wordsworth, W. (1807). Resolution and Independence. Poetry Foundation. Retrieved from https://www.poetryfoundation.org/ poems/45545/resolution-and-independence/ 